\title{
Sophisticated Discipline in a Nascent Deposit Market: Evidence from Post-Communist Russia
}

\author{
Alexei Karas, William Pyle and Koen Schoors
}

\begin{abstract}
Using a database from post-communist, pre-deposit-insurance Russia, we demonstrate the presence of quantity-based sanctioning of weaker banks by both firms and households. Evidence for the standard form of price discipline, however, is weak. This combination of findings is unusual within the context of the literature on market discipline. But it is consistent with depositors interpreting the deposit rate as a complementary proxy of otherwise unobserved bank-level risk. Testing this hypothesis, we estimate the deposit supply function and show that, particularly for poorly capitalized banks, interest rate increases exhibit diminishing, and eventually negative, returns in terms of deposit attraction.
\end{abstract}

JEL: G21, O16, P2

Keywords: market discipline, deposit market, Russia

Karas: Ph.D. student, Department of Economics, Ghent University, Belgium

Pyle: Associate Professor, Economics Department, Middlebury College, Middlebury, VT 05753, wpyle@middlebury.edu; William Davidson Institute, University of Michigan Business School

Schoors: Professor, CERISE, Ghent University, Belgium; William Davidson Institute, University of Michigan Business School, koen.schoors@ugent.be 


\section{Sophisticated Discipline in a Nascent Deposit Market: Evidence from Post-Communist Russia}

Depositors may penalize banks for undertaking risks, performing poorly or otherwise jeopardizing the value of their assets. By withdrawing funds or requiring deposit rate premiums from less stable institutions, their actions have the potential to increase allocative efficiency and mitigate moral hazard. But this sort of quantity or price-based discipline only materializes if depositors possess both the willingness and ability to monitor their banks. Whereas the former depends upon the degree to which deposits are believed to be protected by regulatory oversight and (explicit or implicit) insurance guarantees, the latter requires both access to and understanding of the relevant bank data. While not as much of a concern when depositors are experienced and mechanisms for disseminating financial information are reliable, the ability to discipline banks in settings in which these features are under-developed has been open to question. Indeed, doubts have been expressed as to the private sector's capacity for effective monitoring in countries in which informational structures - such as accounting rules and disclosure requirements - lag behind international standards (Levy-Yeyati et al., 2004). Careful empirical studies, however, that either confirm or cast doubt upon the ability of depositors to discipline banks in immature institutional environments are rare.

Post-communist Russia presents us with a worthy test case of depositors' capacity to provide discipline in a nascent market with under-developed institutions. Concurrent with the systemic transformation launched in the early 1990s, hundreds of private commercial banks entered its new, 
largely un-regulated, deposit market. Not surprisingly, several significant banking crises ensued. And since monies held in non-state banks were uninsured, the country's depositors made quick acquaintance with the private costs of institutional failure. In other words, from soon after the dawn of the new market era, depositors possessed ample motivation to penalize banks known to be performing poorly and/or assuming undue risks. But, as noted, the willingness to impose discipline on institutions recognized as less stable is not tantamount to the ability to do so.

Drawing on a unique database from the pre-deposit-insurance stage of Russia's postcommunist transition, we investigate below whether depositors have actively disciplined private, domestic banks. And we do find that in spite of the country's apparent institutional immaturity, standard measures of the capacity to meet deposit obligations (e.g., capitalization and liquidity) correlate strongly with subsequent deposit inflows. But while evidence for quantity-based discipline is strong and robust, that for the standard form of price-based discipline is not. Clear evidence, that is, that depositors "demand" higher deposit rates from less stable institutions is lacking.

In and of itself, the absence of price discipline should not be interpreted as suggesting that market discipline is weak. Indeed, the combination of strong evidence for quantity disciplining and nearly non-existent support for the standard form of price discipline is consistent with a different type of price discipline that, arguably, is more sophisticated than that uncovered in previous studies. Depositors, we say, exhibit this "sophisticated discipline" if they view the deposit rate as a complementary proxy for institutional stability and not purely as a mechanism through which banks compete for funds and offer compensation for risk or poor performance reflected in their fundamentals. So viewed, banks cannot necessarily expect to increase the net inflow of deposits, ceteris paribus, by raising deposit rates. More than just compensating for observable risk, raising rates may carry the suggestion of additional risk. If so, standard tests for market discipline may not produce strong results and should be complemented by direct estimation of the deposit supply 
function. This would produce evidence consistent with sophisticated discipline if higher rates exhibited diminishing marginal, even negative, returns in terms of deposit attraction.

This article contributes to the general literature on market discipline in two important ways. First, our data allow us to explore the impact of depositor type - i.e., household, firm or bank - on market discipline in a manner not done elsewhere. Second, we estimate depositors' supply function in order to evaluate whether or not the deposit rate is interpreted as a supplementary proxy for bank-level risk. In so doing, we present evidence consistent with this form of sophisticated discipline. The article is divided into five sections. The first provides a review of the relevant literatures on market discipline and Russia's nascent banking sector. Section 2 discusses the empirical methodology, and section 3 presents the data and variables used in the subsequent analysis. We then present our empirical results in section 4, followed by conclusions in section 5 .

\section{Literature and Background}

\subsection{Market Discipline in Deposit Markets}

Much of the evidence for deposit market discipline comes from countries with mature and relatively transparent banking sectors. For instance, a number of studies of partially uninsured large deposits in the United States demonstrate that a bank's cost of funds in one period is associated with previous period measures of depositor risk: low capital-assets ratios (Cook and Spellman, 1994; Hannan and Hanweck, 1988; Park and Peristiani, 1998); high variability of return on assets (Hannan and Hanweck, 1988); higher percentages of bad loans and, generally, lower return on assets (Cook and Spellman, 1994; Park and Perstiani, 1998); and greater exposure to junk bonds (Brewer and Mondschean, 1994). Cook and Spellman (1994), moreover, show that interest rates on wholly insured deposits at S\&L's reflect capitalization and performance measures; even government sponsored "guarantees," after all, may not be ironclad. Finally, Park and Peristiani (1998) 
demonstrate a negative relationship between U.S. thrifts' predicted probability of failure and the subsequent growth of large uninsured deposits. Both price and quantity discipline, in other words, have been shown to prevail in the United States' banking sector, particularly with respect to deposits that are not fully insured. A recent study using cross-country panel data from thirty-two OECD countries confirms the presence of market disciplining behavior in other mature institutional environments as well (Nier and Baumann, 2006).

A few empirically focused studies have pursued this theme in countries with less developed informational infrastructures. Controlling for the presence of deposit insurance and using data from a sample of both OECD and developing countries, Demirgüç-Kunt and Huizinga (2004) find a negative relationship between the implicit cost of bank funds and prior period measures of bank capitalization, profitability and liquidity. The evidence for quantity disciplining, however, is weaker. Indeed, they find no significant relationship between the net growth in bank deposits and earlier measures of either profitability or liquidity. Investigating experiences in Argentina, Chile and Mexico, Martinez-Peria and Schmukler (2001) turn up evidence consistent with the standard forms of both quantity and price discipline. Controlling simultaneously for several measures of bank stability and risk, they demonstrate that banks' deposits increase and their deposit rates generally decrease with a reduction in the percentage of non-performing loans and improvements in liquidity and capitalization. These authors also highlight how the relative magnitude of deposit market discipline increases after banking crises, suggesting that shocks to the sector breed greater depositor vigilance.

Most previous studies of deposit market discipline have not distinguished depositors by type. Although some have examined the role of actors holding deposits of different sizes (Cook and Spellman, 1994; Martinez-Peria and Schmukler, 2001), our data allow us to distinguish depositors by legal status - i.e., non-bank firm, bank or household. While likely to be correlated with deposit size, a party's legal identity may correlate with its willingness and ability to impose discipline. Relative to 
households, for instance, enterprise managers might be presumed to either have better access to or more appreciation for the financial information released by banks. They may also face lower costs of switching institutions, a potentially non-trivial consideration for households, particularly those outside the largest urban areas where retail banking networks are poorly developed.

We are unaware of any previous study that empirically demonstrates a link between quantity discipline and deposit rates. Our inspiration here is drawn from a theoretical framework outlined by Hellman et al. $(1998,2000)$ in which

...depositors can perfectly infer (from the bank's deposit rate and capital base) whether the bank will gamble or invest in the prudent asset ... assumptions [chosen] not for realism but to consider an environment most conducive to solving the moral hazard problem via private monitoring $\left(1998\right.$, p. 5). ${ }^{1}$

From our perspective, the important point in their stylized framework is that deposit rates and capitalization - both independently and through their interaction - determine the net inflow of deposits and, thus, the presence of market discipline. Higher interest rates, particularly for lower levels of capitalization, are interpreted as coincident with a riskier future lending strategy. Depositors, thus, weigh the benefits of higher rates against the increased potential for bank failure. The authors' caveat as to their assumption's realism clearly speaks to a lack of credulity in depositors' actual ability to read banks' behavior in this manner. ${ }^{2}$ So to the extent that such sentiment as to depositor sophistication is widely held, it would seem reasonable to identify any empirical support for the actual interpretation of deposit rates in this manner as evidence of a sophisticated form of discipline.

\subsection{Russia's Nascent Banking Sector}

Russians' temporal experience with liberalized deposit markets has been brief and the country's institutions to support depositor monitoring have had little time to develop. Indeed, Barth 
et al. $(2004,2006)$ recently ranked Russia in the bottom quintile of over one hundred countries on a "private sector monitoring" (PSM) index, a measure meant to capture the quality of institutions that facilitate deposit market discipline. ${ }^{3}$ Although the ranking raises questions about Russian depositors' ability to monitor and discipline banks, it does not provide any sense of their interest in doing so. However, a brief review of Russia's post-communist financial sector development suggests that the intensity of this interest should not be under-estimated.

When financial markets were first permitted in the early 1990s, bank deposits, particularly those of households, were held almost exclusively by Sberbank, the state savings bank. But lax entry policies in the early transition period contributed to the quick development of a robust and competitive market for deposits. By early 1994, on the back of heavy advertising and relatively high interest rates, private banks had captured over half of the household deposit market. The era's mix of liberalized deposit rates, naïve depositors and over-burdened regulators proved dangerous. A system-wide liquidity crisis in 1995 led to bankruptcies of some of the country's largest private retail banks. Their failures followed by only a year the collapse of several high-profile pyramid schemes, the largest of which, MMM, contributed to the loss of savings of up to ten million Russians. In the popular mind, the promise of high returns on savings quickly became associated with institutional instability.

The image problem of private banks was furthered by the macroeconomic crisis of 1998. In August, the Russian government devalued the ruble and defaulted on its bond obligations. Because of their exposure to hard currency liabilities and ruble-denominated assets, including government securities, a number of banks were driven into insolvency. Again, many of the largest players on the retail market proved unable (or in some cases, unwilling) to meet their obligations to depositors (Perotti, 2003; Radaev, 2000; Schoors, 2001; Spicer and Pyle, 2002). 
Russia's relatively short history with liberalized deposit markets explains both depositors' initial naivete in the face of high promised returns and the relative under-development of institutions that facilitate private sector monitoring (Barth et al., 2004 and 2006). But their experiences in the mid-1990s quickly heightened awareness of the private costs of bank failure. Circumstances taught them the benefits of carefully monitoring their financial institutions. Indeed, as has been demonstrated elsewhere, we suspect that the financial crises in Russia have precipitated more vigilant depositor discipline (Martinez-Peria and Schmukler, 2001). Moreover, the conflation of high interest rates with institutional instability that resulted from the crises of the mid-1990s suggests that deposit rates themselves might be interpreted, in part, as a proxy for otherwise unobservable bank risk.

\section{Methodology}

We start by investigating the evidence for market discipline generally and then proceed to look for it in the behavior of specific depositor groups. In so doing, we employ two standard sets of reduced form models:

$$
\begin{aligned}
& \Delta D_{i, t}=\beta^{\prime} \text { Bank }_{i, t-1}+d_{t}+v_{i}+e_{i, t} \\
& i_{i, t}^{d}=\beta^{\prime} \text { Bank }_{i, t-1}+d_{t}+v_{i}+\omega_{i, t}
\end{aligned}
$$

with the number of banks $i=1, \ldots, \mathrm{N}$ and the number of observations per bank $t=1, \ldots, \mathrm{T}^{4}{ }^{4}$ The lefthand side variables are, respectively, the first difference of the log of deposits held by bank $i$ at time $t$, and the (implicit) real interest rate paid on those deposits. Bank $k_{i, t-1}$ is a vector of bank-specific variables assumed exogenous and included with a quarterly lag to account for the fact that financial reports are not instantaneously made available to the public. Time dummies, $d_{t}$, control for macroeconomic shocks that influence the banking system as a whole. ${ }^{5}$ And we allow for unobserved 
bank heterogeneity by introducing a bank-specific, time-invariant effect, $v_{i}$. The error terms, $e_{i, t}$ and $\omega_{i, b}$ are assumed to be independently distributed with mean zero and variance $\sigma_{i, t}^{2}$

In both models (1) and (2), observing the coefficient estimates for the bank-specific variables provides the basis for tests of market discipline. Generally speaking, we look for statistically significant associations between those variables that measure a bank's capacity for responding to deposit withdrawals and its subsequent net deposit flows and deposit rates. All else equal, weaker banks are described as subject to market discipline if they experience less net growth in deposits or if they pay higher deposit rates. Depositors, that is, are presumed to react to the observed weakness by either (a) channeling monies away from weaker institutions or (b) requiring a deposit rate premium as compensation. The two dependent variables provide a more comprehensive test of market discipline than relying upon just one (Martinez-Peria and Schmukler, 2001). ${ }^{6}$

The data allow us to explore the impact of a financial crisis on market discipline by estimating model (1) for periods before and after the August 1998 ruble devaluation and sovereign debt repudiation. By splitting the post-crisis data into sub-periods, we check whether the documented effects remain stable over time. We also test the relationship between depositor identity and market discipline by estimating separate models for both the deposits held by and the deposit rates paid to non-bank firms, households and banks. And last, we run the models both inclusive and exclusive of banks that are state owned or are "pocket banks" who gear lending activity to owners or company insiders. ${ }^{7}$ With respect to all versions, we report within (fixed effects) or pooled estimates depending on whether the fixed effects are jointly significant.

We employ a new and separate model to test for sophisticated discipline in which the deposit rate itself serves as a complementary proxy of institutional stability. As such, rate increases amount to more than a means to attract deposits or offer compensation for increased risk, ceteris 
paribus. They are interpreted, as well, as coincident with an increase in risk not reflected in other observed measures (Hellman et al., 1998, 2000). If higher deposit rates, particularly in combination with other risk measures (e.g., low capitalization), are so interpreted, the effect of raising interest rates on the volume of deposits supplied will not necessarily be positive. The deposit supply curve, that is, may be backward bending.

We directly estimate the supply function employing the following two specifications:

$$
\begin{aligned}
& \Delta D_{i, t}=\beta^{\prime} \operatorname{Bank}_{i, t-1}+\delta_{1} i_{i, t}^{d}+\delta_{2}\left(i_{i, t}^{d}\right)^{2}+d_{t}+v_{i}+\varepsilon_{i, t} \\
& \Delta D_{i, t}=\beta^{\prime} \operatorname{Bank}_{i, t-1}+\delta_{1} i_{i, t}^{d}+\delta_{2}\left(i_{i, t}^{d}\right)^{2}+\delta_{3} i_{i, t}^{d} *\left(1-\operatorname{Cap}_{i, t-1}\right)+\delta_{4} i_{i, t}^{d} *\left(1-\operatorname{Cap}_{i, t-1}\right)^{2}+d_{t}+v_{i}+\varepsilon_{i, t}
\end{aligned}
$$

where the real deposit rate, $i_{i, t}^{d}$, its square and its interaction with a measure of bank capitalization, (with $\mathrm{Cap}_{i, t-1}$ representing the capital-assets ratio) and its square, are included to test for the joint effect of price and risk measures and for the hypothesized backward-bending supply curve. Bank $k_{i, t-1}$ is a vector of exogenous supply shifters - the same as employed in models (1) and (2), with the exception being that we exclude those regressors that had been either consistently insignificant or unstable and rarely significant in the prior estimations.

Our identification strategy (i.e., the choice of instruments for the endogenous deposit rate) relies on the assumption that a bank's demand for deposits is affected by the risk-return profile of its available investment opportunities. Since a bank's average lending rate reflects this risk-return profile, we regard the rate as a determinant of its demand for deposits. ${ }^{8}$ On the other hand, it is difficult to fathom how lending rates would enter into depositors' supply decision. Although consumer lending rates are often advertised, consumer lending represented less than five percent of total bank loans during the period analyzed. ${ }^{9}$ Of course, depositors could access the same data used here to calculate, with a lag, average lending rates. Though arguably possible, it would seem improbable that 
depositors actually use this approach to evaluate a bank's stability. Nevertheless, in unreported robustness tests, we included the lagged average (implicit) lending rate and found it entered the supply function regressions with a highly insignificant coefficient and had no impact on our main results.

We employ the Difference Generalized Method of Moments estimator (GMM) proposed by Arellano and Bond (1991). Terms involving the deposit rate are treated as endogenous. The bank's average (implicit) lending rate, its square, as well as suitably lagged values of endogenous variables are used as instruments. We employ the Hansen-Sargan test of over-identifying restrictions and the Arellano-Bond test of second-order serial correlation to test the validity of the chosen instruments. Finally, we split banks into sub-samples of small and large banks and check whether the documented effects depend on bank size.

\section{Data and Variables}

All banks are required to disclose their financial statements to the Central Bank of Russia (CBR). Balance sheet information and profit and loss accounts are reported, respectively, on monthly and quarterly bases and are made available to the public through several channels. Since 1999, the financial statements of most banks have been posted on the website of the CBR (www.cbr.ru). Banks publish their balances in the financial press such as the monthly financial periodical Den'gi $i$ Kredit. Private information agencies, moreover, in cooperation with the CBR, gather raw, bank-specific accounting data to generate standardized financial indicators. Some of this processed data is made available for free (e.g. online at www.banks-rate.ru), whereas the most detailed information can only be accessed through fee-based channels.

The bank data used in the analysis here were made available to the authors by two established and highly respected private financial information agencies, Interfax and Mobile. ${ }^{10}$ The 
former provides quarterly measures of bank balances and profit and loss accounts as well as bankspecific scores on a battery of regulatory standards from 1999 through 2002. The latter offers bank balances on a monthly basis from mid-1995 through 2002 and profit and loss accounts on a quarterly basis from October 2000 through 2002. As the profit and loss data are required for constructing implicit interest rates and efficiency ratios, we limit our analysis to quarterly observations. The absence of profit and loss data before 1999 inhibits us from investigating price discipline prior to that year.

We merge quarterly observations of the two datasets (both expressed in rubles) by date and bank registration number. For those cases in which a bank merged or was acquired, we treat the resulting larger bank as "new" from the standpoint of our sample. However, given the requisite differencing and lagging in our analysis, this requires dropping at least the first two observations for this "new" bank. To avoid this loss of data, we sum up the financial statements of the two merging banks for the two quarters preceding the merger and use those merged accounts as the needed lags. ${ }^{11}$

The bank-specific variables used in this paper include deposits and interest rates as well as measures of risk, performance and balance sheet structure. The average implicit interest rate that a bank offers on its deposits has been calculated by dividing interest expenses during a particular period by the corresponding level of deposits (Martinez-Peria and Schmukler, 2001). ${ }^{12}$ Since our dataset disaggregates both interest expenses and deposits by the legal status of the depositor, the variables measuring deposit flows and interest rates can be constructed separately for non-bank firms, households and banks. Similar procedures were used to compute the implicit lending rate.

As depositors are hypothesized to react to observable data, we consider bank-specific measures of risk and performance that can be easily constructed using publicly available information (e.g., online at www.banks-rate.ru). Other, more sophisticated measures suggested in the literature 
could either not be constructed from the available data or did not exist on a comprehensive basis (e.g., bank ratings) over the sample period (Flannery and Sorescu, 1996; Sironi, 2003).

Capitalization, measured as the ratio of capital over assets, is expected to be positively associated with the subsequent growth of real deposits and inversely related to the next quarter's deposit rates. As much as any single measure of bank stability, it has been shown to serve as the basis for market discipline by depositors (Cook and Spellman, 1994; Hannan and Hanweck, 1988; Park and Peristiani, 1998; Martinez-Peria and Schmukler, 2001; Demirgüç-Kunt and Huizinga, 2004).

In general, one would expect liquidity to have the same effect as capitalization with respect to market discipline. Highly liquid banks, that is, should be considered more capable of accommodating unexpected withdrawals (Martinez-Peria and Schmukler, 2001; Demirgüç-Kunt and Huizinga, 2004). We therefore expect a bank's current liquidity ratio - i.e., the sum of its liquid assets divided by the sum of its liabilities on demand accounts and accounts up to 30 days - to be positively associated with deposit growth and negatively with interest rates, ceteris paribus.

The relationship of market disciplining behavior and a second measure of liquidity, excess reserves (relative to assets) deposited with the central bank, is not a priori clear. In a more mature market economy, we might expect excess reserves to measure the capacity to meet the demand for deposit withdrawals. We should consider, however, that Russian banks engaging in speculative activities and wishing to conceal the nature of their business often clear their position and park their monies with the CBR when the accounts are closed. High excess reserves may thus be related to greater risk and thus lower deposit growth and higher deposit rates. It is also possible that high excess reserves may be a function more of problems in the payment system than a desire to maintain excess liquidity for deposit withdrawals (Schoors, 2001). 
Controls are also included for measures that directly capture bank performance. Higher returns relative to assets, we would expect, will increase the stability of deposit institutions and make them less prone to market disciplining (Demirgüç-Kunt and Huizinga, 2004). Moreover, the change in a bank's share of non-performing loans, a measure of a bank's most recent risk management practices, should be inversely related to deposit growth and positively associated with interest rates (Cook and Spellman, 1994; Martinez-Peria and Schmukler, 2001; and Park and Peristani, 1998).

We also take into account efficiency considerations by controlling for operational costs relative to bank size. If we were to assume a homogenous level of service quality across banks, higher personnel expenses as a share of assets should be related to more sanctioning actions. Less cost-effective banks, that is, should be perceived as less stable and, thus, more prone to deposit outflows or pressure to raise deposit rates. On the other hand, since most Russian banks have been known to operate with poorly trained staffs, higher personnel costs may be interpreted as associated with a higher level of human capital and, thus, better asset management and a more stable institution. The expected sign, therefore, is not clear.

Variables capturing balance sheet structure are included as controls as well. Although the literature does not generally consider them as proxies for stability or performance in studies of market discipline, it is at least possible that, ceteris paribus, they could be interpreted as such. In this respect, the expected sign for loans to non-banks as a share of assets is not a priori clear, in part because we cannot distinguish loans either by risk or maturity. A high share of loans to non-banks could either signal greater credit risk or indicate a greater predisposition to engage in more traditional and, perhaps, less speculative activities. The relationship between lending to households as a share of all loans is similarly ambiguous. On the one hand, few Russians have well-developed credit records, making lending to them a risky proposition. However, loans to households may have shorter maturities and thus expose lenders to less liquidity risk. 
Controls for the structure of bank liabilities are also included. Term deposits as a share of all non-bank claims partly capture the maturity structure of liabilities. Banks capable of attracting time deposits have effectively had their stability certified by previous depositors, thus making them potentially less prone to market discipline. However, since term deposits tend to command higher interest rates than demand deposits, the relationship between this variable and the standard form of price-based market discipline is not altogether clear. Growth in term deposits, all else equal, will produce higher payments to depositors. But to the extent that this growth is interpreted as a signal of depositor-conferred stability, we would expect there to be downward pressure on any deposit risk premium. We thus do not have a clear expectation as to the sign on this variable.

Table 1 summarizes our predictions for the signs of the coefficients on the right-hand side variables. Table 2 presents summary statistics for all banks included in our sample. Deposit growth, interest rates and return on assets are all expressed in real terms using Consumer Price Index data from the CBR. ${ }^{13}$ Deposit growth has been positive across all three depositor types but has been fastest over this period among households. As is apparent in rows 5 to 8 , firm deposits represent the largest share of bank liabilities, followed by those of households and then banks. The negative values of implicit real interest rates in Table 2 are consistent with the CBR's data on inflation and announced nominal deposit and lending rates. The lowest implicit real interest rates are paid on firms' deposits, whereas the highest are paid on inter-bank funds.

There are 155 banks in our sample that report negative capital at least once during the period under consideration, with most of these cases occurring in the aftermath of the 1998 financial crisis. Panel B of Table 2 presents the summary statistics for the pre- and the post-crisis periods separately. The standard deviation of key variables - e.g., capitalization and liquidity - is comparable across these periods. 
As was noted in the previous section, we check the robustness of our empirical results by performing all estimations both with and without state-owned as well as "pocket" banks. Because of their access (real or presumed) to public resources, the former are generally believed to provide depositors with weak incentives for monitoring and disciplining (Caprio and Honohan, 2004; Nier and Baumann, 2006). Indeed, in Russia, state-owned banks have enjoyed a number of advantages over their private competitors, including privileged access to state funds, de facto exemption from some regulatory standards, and during the entirety of the period covered by our data, explicit backing for their retail deposits (Tompson, 2004). For the purposes of our analysis, we can distinguish between two types of state-owned banks in Russia, those owned by the CBR and those owned by federal or regional authorities or other government entities. ${ }^{14}$ The former (Sberbank, $V$ neshtorgbank and Vnesheconombank) have enjoyed the full and consistent backing of the CBR and so, considering them less likely to have been subject to market discipline, are excluded from our sample. The second group, however, includes institutions that have been allowed to fail (e.g., Unikombank, Soto-bank, Trade-bank), although the state formally guarantees their household deposits (Civil Code of Russia, article 840). We include these banks in the estimations since they may well have been disciplined by other depositor classes. ${ }^{15}$

To identify "pocket" banks, which have geared their lending activities heavily toward owners and insiders, we use two regulatory standards: owner exposure (the aggregate amount of credits and loans extended to the bank's shareholders or partners) and insider exposure (the aggregate amount of credits and loans extended to employees and managers). ${ }^{16}$ The respective legal thresholds that are not to be exceeded are 50\% and 3\% of the bank's equity capital. First, we define an institution as a "pocket" bank if during our sample period it violates each of these two standards at least once. However, the number of banks identified by this procedure, roughly forty, is small. Considering, moreover, that banks might manipulate their books in order to satisfy these regulatory standards, we 
relaxed the definition by reducing the thresholds to $66 \%$ (definition 1) and further to $33 \%$ (definition 2) of the respective legal thresholds. We thus characterize an institution as a "pocket" bank if, during our sample period, it breaches each of these revised thresholds at least once.

\section{Results}

We lay out our main results in two sections. First, we present and discuss the standard market discipline model, examining how measures of bank risk in one quarter relate to the subsequent quarter's net deposit flows and interest payments. In a second section, we test whether depositors interpret deposit rates as complementing standard measures of bank risk. To save space, the tables report only the variables of economic interest, not the time dummies.

\subsection{Market discipline and depositor type}

This section presents our findings as to whether or not we observe standard forms of market discipline behavior in Russia. Table 3 displays estimation results for the deposit flow model (1) for the pre-crisis period (April 1997 - July 1998), the post-crisis period (October 1999 - January 2003) and 6 sub-periods after the crisis. In broad terms, the results confirm the presence of market discipline. Most notably, a higher capital-assets ratio and greater liquidity predict greater net deposit inflows in the subsequent period. Although these findings hold up both before and after the 1998 crisis, discipline exercised in response to these variables seems to have increased substantially in its aftermath. ${ }^{17}$ This result is consistent with the proposition that crises breed greater depositor vigilance (Martinez-Peria and Schmukler, 2001). Further, the relationship between deposit flows and these two measures of bank risk is shown to be robust across all post-crisis sub-periods.

We also see evidence in support of the presence of market discipline both before and after the crisis in the negative and statistically significant correlation between deposit growth and the increase in non-performing loans. This relationship, however, is not as strong as the findings for 
capitalization and liquidity and is shown not to be robust to the segmentation of periods after 1998. And, interestingly, return on assets is not consistently correlated with net deposit inflows after the crisis, even though it was before. It is possible that Russian depositors have learned not to put too much weight on the profitability rates posted by Russian banks. Indeed, Malyutina and Parilova (2001) note that "It has already become a conventional wisdom that official figures for profits of Russian banks are the most manipulated and thus unreliable ones."

We should note, as well, that after the crisis excess reserves with the CBR are negatively associated with deposit inflows, which suggests that it might be interpreted as a proxy for a riskier asset management strategy. Moreover, one balance sheet structure variable - loans to non-bank firms as a share of total assets - was statistically insignificant before the 1998 crisis but becomes significant and positive in its aftermath. This latter finding is also at least consistent with the proposition that depositors feel safer with banks appearing to engage in more traditional and, perhaps, less speculative investment activities. Finally, we observe banks that pay their personnel more, ceteris paribus, are more successful in attracting funds.

In Table 4, we lay out the results for the model that uses the deposit rate as the dependent variable. In terms of providing evidence for market discipline, the results are clearly weaker than those noted in Table 3. Although the negative signs on the capitalization and liquidity measures are what we would expect if depositor discipline were present, the statistical significance of these associations is not strong and does not hold up to the decomposition across sub-periods. Specifically, there is no evidence that weakly capitalized banks pay higher interest rates to depositors as compensation. We also find only weak evidence that depositors accept higher interest rates in return for lower liquidity. Finally, we do not see any significant relationship between the dependent variable and either the bank's profitability or its increase in non-performing loans. The relatively high explanatory power of the regressions is largely due to time dummies. In sum, our results 
strongly confirm the presence of quantity discipline but offer little to no support for the standard form of price discipline.

In Table 5, we repeat the main equations of Tables 3 and 4 for the three depositor types: non-bank firms, households and banks. The results confirming quantity discipline, particularly in the post-crisis period, appear to be driven most strongly by the behavior of firms. As can be observed, firm deposits are much more sensitive to liquidity, the change in loan quality and the capital-assets ratio than those of households or banks. Households, however, do display some sensitivity to each of these measures, particularly in the post-crisis period. As depositors in other institutions, banks are shown to be responsive to capitalization in the post-crisis period but little else.

Disaggregated by depositor legal status, the results for the standard form of price discipline are, again, not as strong. Table 5 demonstrates only weak and sporadic associations between increased bank risk and the "demands" of firms, households or banks for compensation in the form of higher deposit rates. Only among firms (but not households or banks), do we observe a negative and statistically significant association between capitalization and subsequent deposit rates. And only among households and banks (but not firms), do we see a similar relationship between these rates and liquidity. And, notably, with respect to non-performing loans and profitability, we do not observe any evidence for the standard form of price discipline among any of the depositor types.

We include Table 6 to demonstrate the general robustness of our results to the exclusion of state banks and "pocket" banks, variously defined. Most notably, capitalization and liquidity remain strong predictors of deposit flows but, at most, only weak predictors of subsequent interest rates.

\subsection{Sophisticated discipline}

Among studies of deposit market discipline, our finding of strong evidence for quantity disciplining but weak support for the standard form of price discipline stands out as unique. But, as 
we noted earlier, this result should not be interpreted, in and of itself, as suggesting that market discipline is weak. Indeed, our finding is consistent with a different, perhaps more sophisticated, form of price discipline in which deposit rates represent more than just a mechanism for competing for funds and compensating depositors for observable risk.

We now explore the manner in which deposit rates might complement other variables that capture a bank's prospects for honoring its liabilities. Specifically, we ask whether these rates are interpreted as a signal of bank stability (Hellman et al., 1998 and 2000). If they are, we should not expect there to be a clear positive relationship between the rates a bank posts and its subsequent ability to attract deposits, perhaps especially for banks already viewed as weak with respect to other measures, such as capitalization.

Table 7 presents estimations of the deposit supply function, using specifications (3) and (4). We first report results for all banks, then inclusive of just non-state banks and non-"pocket" banks, variously defined. Both specifications (3) and (4) allow for a non-linear relationship between interest rates and deposits such that after a certain "switching point" the slope of the supply curve can change sign. In specification (4), the interest rate is interacted with capitalization to investigate whether the price elasticity of deposit supply is sensitive to an observed measure of bank risk (Hellman et al., 1998 and 2000). All reported equations pass both the Hansen test of over-identifying restrictions and the Arellano-Bond test of second-order serial correlation at conventional significance levels.

The results in Table 7 demonstrate a non-linear interest rate effect in the columns that represent specification (3), suggesting an implied switching point of six percent, above which increases in real interest rates produce negative returns with respect to deposit attraction. ${ }^{18}$ In addition, in the columns that represent specification (4), we observe a joint effect of interest rates 
and capitalization on deposit growth. The implied switching point of roughly twelve percent appears stable across sample definitions. Both the independent and interaction effects of interest rates and bank capitalization can be viewed in Figure 1, which shows the deposit growth plane in the interest rate/capitalization space, evaluated at the average values of the other independent variables. At low and intermediate interest rate levels, a bank's deposit growth in response to interest rate hikes is positively correlated with bank capitalization. Moreover, higher capitalization is positively correlated with the switching point beyond which interest rate increases produce negative returns with respect to deposit attraction. Panel A shows the results for all banks in our sample and Panel B shows them for banks that are neither state-owned nor "pocket" banks.

This evidence is consistent with depositors growing suspicious as interest rates rise. Their suspicion, moreover, that interest rate hikes might reflect new sources of bank risk, not otherwise observed, is sensitive to an observed measure that all our results have suggested is important to market disciplining behavior - i.e., capitalization. In other words, the evidence suggests that if depositors are confident in a bank's ability to meet deposit withdrawals, on the basis of its capitalassets ratio, they are more apt to view its rate increases as coincident with increases in the expected return on their deposits and, thus, increase their supply of deposits accordingly. But a bank which already has given depositors reason for suspicion, due to its lower capitalization, does not have the same ability to translate its increase in deposit rates into a corresponding increase in the expected returns and, thus, the deposits of its depositors.

Table 8 demonstrates that our results are not driven by size effects. We split the sample into two sub-samples - the smallest $80 \%$ and the largest $20 \%$ - and re-estimate specification (3) for both. Although large banks' deposits are less sensitive to capitalization and liquidity than the deposits of small banks, both sub-samples show evidence of more sophisticated discipline. Small banks exhibit an implied switching point of five percent while large banks enjoy a higher switching point of eleven 
percent, above which increases in real interest rates produce negative returns with respect to deposit attraction. Figure 2 shows deposit growth as a function of the deposit rate for large and small banks respectively, evaluated at the average values of the other independent variables. At low interest rates deposits of small banks grow faster than those of large banks, but this deposit growth reaches a turning point if real interest rates exceed five percent. The lines cross at a real rate of about nine percent, above which the deposit growth of large banks really dominates the deposit growth of small banks.

One might well question the logic of the backward bending deposit supply curve since it might appear to be at odds with profit-maximizing behavior. If there are two interest rates that generate the same deposit inflow, why would a bank ever choose the higher one? We should recall here that in a nascent market environment, it is not unreasonable to expect that bank managers will still be learning about the nature of depositors' deposit supply function, particularly given its possible re-orientation in the aftermath of severe financial crises. In other words, given banks' imperfect information about what this function looks like, their behaviour is not necessarily inconsistent with rationality.

\section{Conclusion}

Even though the deposit market in Russia is young and its supporting institutional / informational infrastructure is relatively immature, the country's depositors have developed the capacity to identify and discipline weaker banks. Banks net deposit inflows, specifically, have been shown to be highly sensitive to measures of bank capitalization, liquidity and changes in loan quality, particularly after the financial crisis of 1998. Quantity disciplining, moreover, appears to have been driven primarily by the behavior of non-bank firms and, to a lesser extent, households. This finding is consistent with firm managers having greater knowledge of the relevant banking data and its 
meaning. Nevertheless, the evidence that households have developed a capacity for disciplining banks is noteworthy and may in part be a reflection of their experience with bank failures earlier in the country's post-communist transition.

The strong presence of quantity discipline and the relative absence of price discipline, at least as traditionally conceived, present us with a combination of findings not observed in prior studies. Rather than interpreting the latter as weakening the case for market discipline, we view it as consistent with a more subtle form of discipline than that which has been explored in other contexts. Indeed, we observe that the supply of deposits is highly sensitive to deposit rates and, importantly, that increases in those rates ultimately produce a decrease in deposit inflows. This effect, moreover, is particularly pronounced for banks already viewed as weak because of their low capitalization. The deposit rate, thus, appears to be viewed by depositors not solely as a bank's promised payment for funds but also as a proxy for otherwise unobservable risk. It is at least conceivable that because a subset of bank managers have yet to fully understand this interpretation, some banks may continue to raise their rates only to see their stock of deposits decline.

In terms of reduced market discipline and subsequent moral hazard incentives, our results do suggest a real cost as Russia now moves forward with the introduction of widespread deposit insurance. But more generally, given the doubt that has been expressed as to whether depositors in nascent markets will be both willing and able to discipline the banks entrusted with their funds, our findings offer support for the proposition that markets and market actors develop mechanisms and strategies to mitigate market failures with greater speed than perhaps initially thought. We should remember, however, that the post-communist experience with bank failures has imposed great costs across Russian society and effectively forced depositors to become the relatively quick learners and sophisticated discipliners that can now be observed in these data. 


\section{References}

Arellano, Manuel and Stephen Bond. (1991). "Some Tests of Specification for Panel Data: Monte Carlo Evidence and an Application to Employment Equations." Review of Economic Studies 58, 277-297.

Barth, James, Gerard Caprio and Ross Levine. (2006). Rethinking Bank Regulation: Till Angels Govern. New York: Cambridge University Press.

Barth, James, Gerard Caprio and Ross Levine. (2004). "Bank Regulation and Supervision: What Works Best?” Journal of Financial Intermediation 13, 205-248.

Berezanskaya, Yelena. (2003). "Nastoyaschi Kreditnyi Bum Nachnets'a cherez God.” Vedomosti, November 24, 2003.

Berger, Allen. (1995). “The Relationship between Capital and Earnings in Banking." Journal of Money, Credit and Banking 27, 432-456.

Bond, Stephen. (2002). "Dynamic Panel Data Models: A Guide to Micro Data Methods and Practice." CeMMAP Working Paper 09/02.

Brewer, Elijah, and Thomas Mondschean. (1994). "An Empirical Test of the Incentive Effects of Deposit Insurance: The Case of Junk Bonds at Savings and Loan Associations.” Journal of Money, Credit and Banking 26, 146-164.

Caprio, Gerard and Patrick Honohan (2004). "Can the Unsophisticated Market Provide Discipline?" In Market Discipline across Countries and Industries, edited by Claudio Borio, William Hunter, George Kaufman and Kostas Tsatsaronis, pp. 349-362. Cambridge: MIT Press. 
Cook, Douglas and Louis Spellman. (1994). "Repudiation Risk and Restitution Costs: Toward Understanding Premiums on Insured Deposits.” Journal of Money, Credit and Banking 26, 439-459.

Demirgüç-Kunt, Asli and Harry Huizinga. (2004). "Market Discipline and Financial Safety Net Design." Journal of Monetary Economics 51, 375-399.

Flannery, Mark and Sorin Sorescu. (1996). "Evidence of Bank Market Discipline in Subordinated Debenture Yields: 1983-1991." Journal of Finance 51, 1347-1377.

Hannan, Timothy and Gerald Hanweck. (1988). "Bank Insolvency and the Market for Large Certificates of Deposit.” Journal of Money, Credit and Banking 20, 203-211.

Hanousek, Jan and Gerard Roland. (2001). "Banking Passivity and Regulatory Failure in Emerging Markets: Theory and Evidence from the Czech Republic.” William Davidson Institute Working Paper 424.

Hellman, Thomas, Kevin Murdock and Joseph Stiglitz. (2000). "Liberalization, Moral Hazard in Banking, and Prudential Regulation: Are Capital Requirements Enough?” American Economic Review 90, 147-165.

Hellman, Thomas, Kevin Murdock and Joseph Stiglitz. (1998). "Liberalization, Moral Hazard in Banking, and Prudential Regulation: Are Capital Requirements Enough?” Graduate School of Business, Stanford University, Working Paper 1466R.

Karas, Alexei and Koen Schoors. (2005). "Heracles or Sisyphus? Finding, Cleaning and Reconstructing a Database of Russian Banks.” Ghent University Working Paper 05/327.

Levy-Yeyati, Eduardo, Maria Martinez-Peria and Sergio Schmukler. (2004). "Market Discipline in Emerging Economies: Beyond Bank Fundamentals." In Market Discipline across Countries 
and Industries, edited by Claudio Borio, William Hunter, George Kaufman and Kostas Tsatsaronis, pp. 135-146. Cambridge: MIT Press.

Malyutina, Marina and Svetlana Parilova. (2001). "The Determinants of Excessive Risk-taking by Banks in Transition." Unpublished manuscript, Economics Education and Research Consortium-Russia and CIS.

Martinez-Peria, Maria and Sergio Schmukler (2001). "Do Depositors Punish Banks for Bad Behavior? Market Discipline, Deposit Insurance, and Banking Crises." Journal of Finance $56,1029-1051$.

Matovnikov, Mikhail. (2002). “Nadezhnost' Banka Tesno Svyazana so Strukturoi ego Aktsionernogo Kapitala." Tsentr Ekonomicheskogo Analiza-Interfax, Moscow.

Mamontov, A. (2005). “Gosudarstvo v Bankakh: Zlo ili Blago?” Natsional'nyi Bankovskii Zhurnal $12,24$.

Nier, Erlend and Ursel Baumann. (2006). "Market Discipline, Disclosure and Moral Hazard in Banking." Journal of Financial Intermediation 15, 332-361.

Perotti, Enrico. (2002). "Lessons from the Russian Meltdown: The Economics of Soft Legal Constraints." International Finance 5, 359-399.

Radaev, Vadim. (2000). "Return of the Crowds and Rationality of Action: A History of Russian Financial Bubbles in the Mid-1990s." European Societies 2, 271-294.

Schoors, Koen. (2001). “The Credit Squeeze during Russia’s Early Transition: A Bank-based View.” Economics of Transition 9, 205-228.

Sherif, Khaled, Michael Borish and Alexandra Gross, (2003). State-owned Banks in the Transition: Origins, Evolution and Policy Responses. World Bank, Washington, D.C. 
Sironi, Andrea, "Testing for Market Discipline in the European Banking Industry: Evidence from Subordinated Debt Issues.” Journal of Money, Credit and Banking 35, 443-472.

Spicer, Andrew and William Pyle. (2002). "Institutions and the Vicious Circle of Distrust in the Russian Household Deposit Market, 1992-1999.” In Advances in Strategic Management: The New Institutionalism in Strategic Management, edited by Paul Ingram and Brian Silverman, pp. 371-396. New York: JAI Press.

Stiglitz, Joseph. (1994). Whither Socialism? Cambridge: MIT Press.

Stock, James and Motohiro Yogo. (2002). "Testing for Weak Instruments in Linear IV Regression.” NBER Technical Working Paper 284.

Tompson, William. (2004). Banking Reform in Russia: Problems and Prospects. OECD Economics Working Paper \#410.

\section{References for Russian banking legislation}

Civil Code of the Russian Federation, part I.

Instruction No.1 of October 1, 1997, "On Bank Regulation Procedure" 
Table 1. Empirical Predictions

\begin{tabular}{l|cc}
\hline \multicolumn{1}{c|}{ Bank-specific explanatory variables } & Expected sign with the following variable as a regressand: \\
Deposit growth & Deposit rate \\
Capital / Total assets & + & - \\
Liquid assets / Demand liabilities & + & - \\
Change in loan quality & - & + \\
Return on assets & + & $?$ \\
Excess reserves / Total assets & $?$ & $?$ \\
Loans to non-banks / Total assets & $?$ & $?$ \\
Loans to households / Loans to non-banks & $?$ & $?$ \\
Term deposits / Total deposits & + & $?$ \\
Personnel expenses / Total assets & $?$ & Not included \\
Deposit rate & + & Not included \\
Deposit rate ^2 & - & \\
\hline
\end{tabular}


Table 2. Summary Statistics, Panel A: 1997-2002

\begin{tabular}{|c|c|c|c|c|c|}
\hline Variable & Obs & Mean & Std. Dev. & Min & $\operatorname{Max}$ \\
\hline Total deposit growth & 26023 & 0,03 & 0,61 & $-7,73$ & 12,96 \\
\hline Firm deposit growth & 26011 & 0,03 & 0,72 & $-8,83$ & 9,18 \\
\hline Household deposit growth & 24187 & 0,05 & 0,89 & $-9,63$ & 12,14 \\
\hline Bank deposit growth & 9497 & 0,00 & 1,20 & $-13,06$ & 12,91 \\
\hline Total deposits / Total assets & 26023 & 0,40 & 0,20 & 0,00 & 0,98 \\
\hline Firm deposits / Total assets & 26023 & 0,27 & 0,18 & 0,00 & 0,97 \\
\hline Household deposits / Total assets & 26023 & 0,09 & 0,09 & 0,00 & 0,76 \\
\hline Bank deposits / Total assets & 26023 & 0,05 & 0,10 & 0,00 & 0,93 \\
\hline Interest rate on total deposits & 16858 & $-0,02$ & 0,03 & $-0,07$ & 0,44 \\
\hline Interest rate on firm deposits & 16517 & $-0,03$ & 0,02 & $-0,07$ & 0,44 \\
\hline Interest rate on household deposits & 15150 & 0,00 & 0,07 & $-0,07$ & 0,48 \\
\hline Interest rate on bank deposits & 7134 & 0,01 & 0,07 & $-0,07$ & 0,46 \\
\hline Interest rate on total loans & 16402 & 0,01 & 0,05 & $-0,07$ & 0,45 \\
\hline Interest rate on firm loans & 16263 & 0,01 & 0,05 & $-0,07$ & 0,43 \\
\hline Interest rate on household loans & 15038 & 0,02 & 0,06 & $-0,07$ & 0,43 \\
\hline Interest rate on bank loans & 8238 & 0,02 & 0,09 & $-0,07$ & 0,47 \\
\hline Capital / Total assets & 26023 & 0,28 & 0,20 & $-0,87$ & 0,99 \\
\hline Liquid assets / Demand liabilities & 26023 & 0,63 & 0,79 & 0,00 & 9,99 \\
\hline Bad loans / Total loans & 26023 & 0,05 & 0,13 & 0,00 & 1,00 \\
\hline Return on assets & 26023 & $-0,03$ & 0,03 & $-0,50$ & 0,93 \\
\hline Excess reserves / Total assets & 26023 & 0,10 & 0,12 & 0,00 & 0,96 \\
\hline Loans to non-banks / Total assets & 26023 & 0,41 & 0,20 & 0,00 & 0,99 \\
\hline Loans to households / Loans to non-banks & 26023 & 0,12 & 0,19 & 0,00 & 1,00 \\
\hline Term deposits / Total deposits & 26023 & 0,31 & 0,25 & 0,00 & 1,00 \\
\hline Personnel expenses / Total assets & 16954 & 0,01 & 0,01 & 0,00 & 0,26 \\
\hline \multicolumn{6}{|c|}{$\begin{array}{l}\text { Note: The table presents the summary statistics of the bank-specific variables with each observation representing } \\
\text { a measure for a single bank in a specific quarter. Only observations used in at least one of the regressions are } \\
\text { included. }\end{array}$} \\
\hline
\end{tabular}


Table 2. Summary Statistics, Panel B: Pre-crisis and Post-crisis

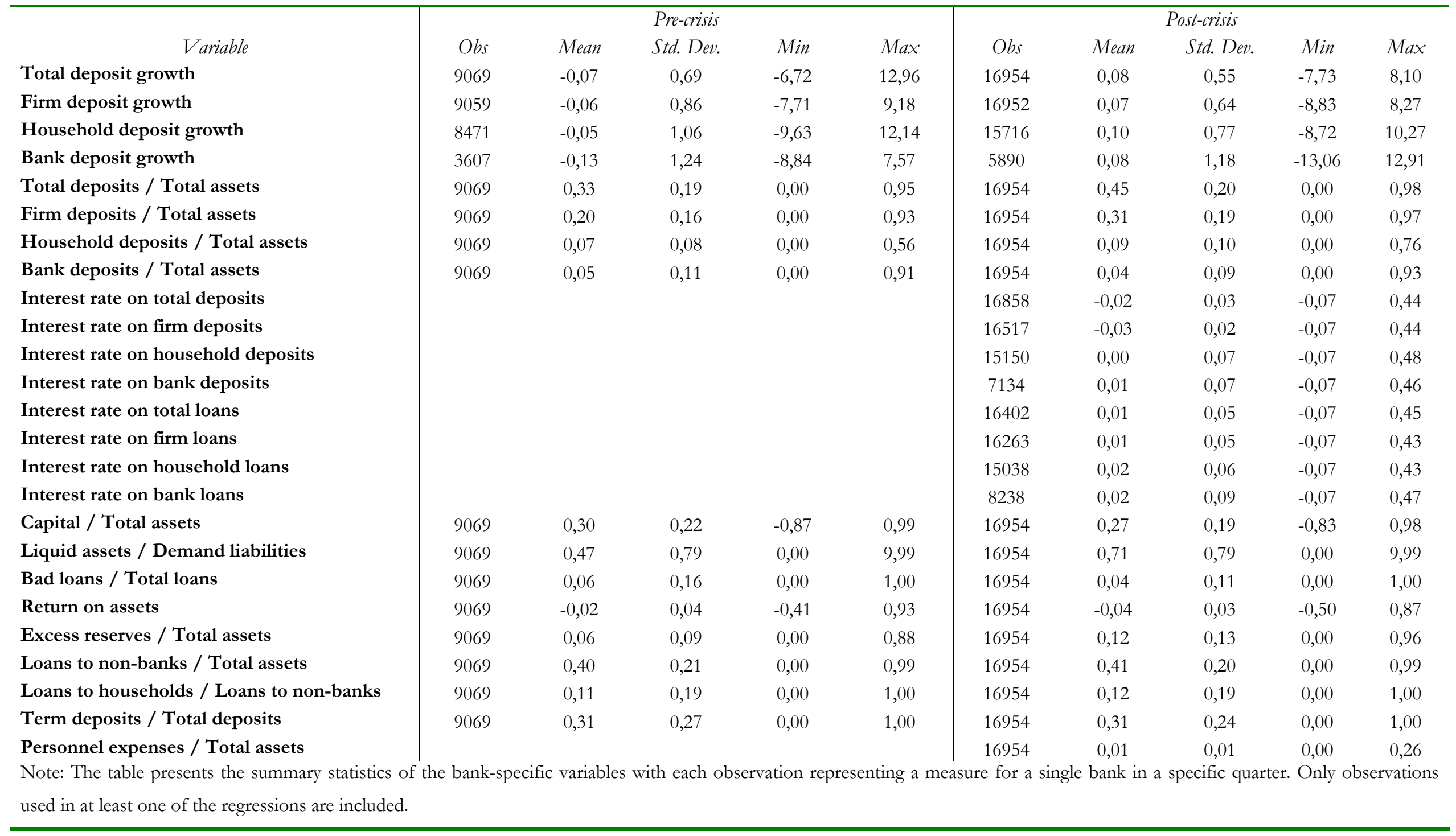


Table 3. Response of Growth of Total Deposits to Bank Risk Characteristics

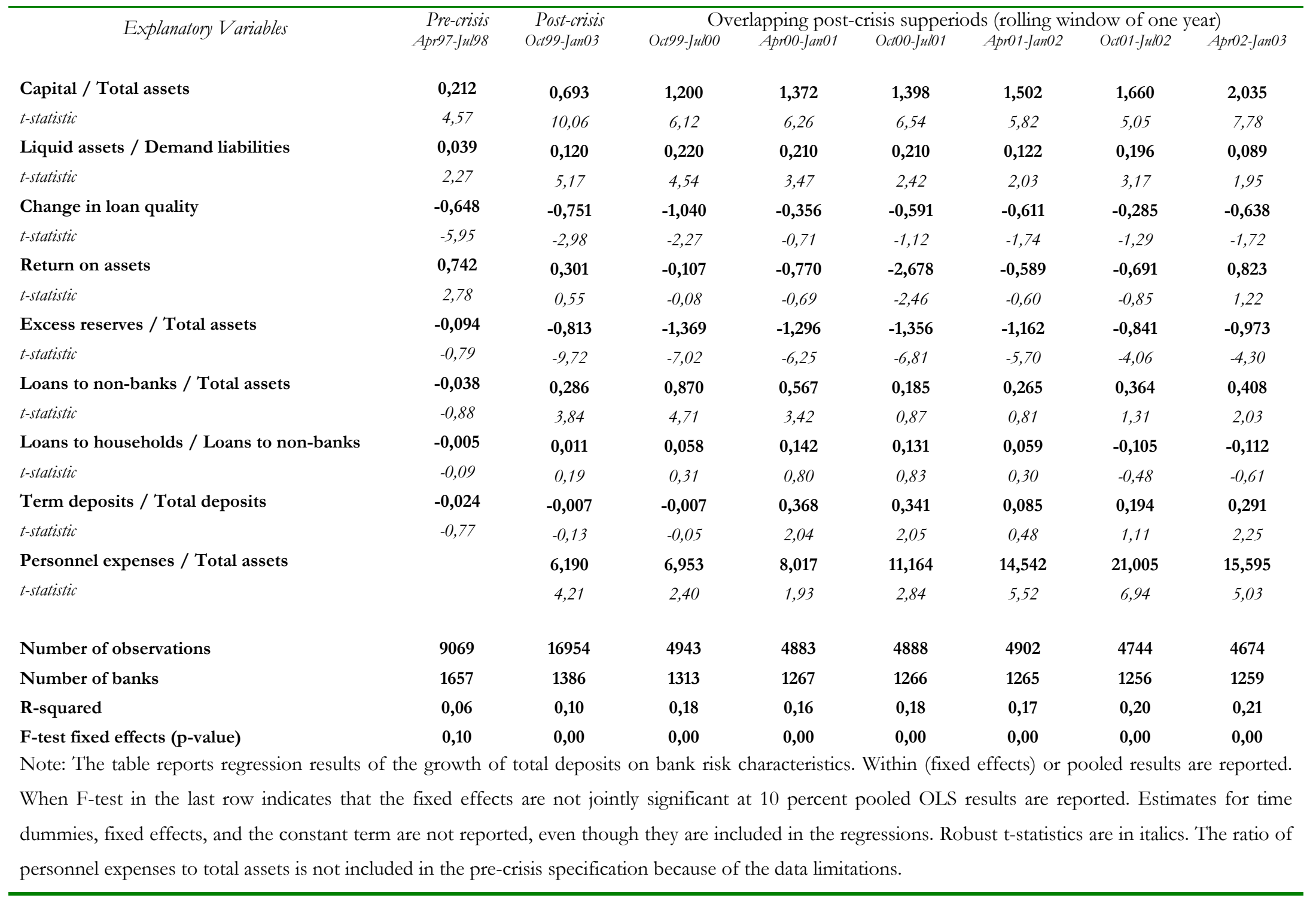


Table 4. Response of Interest Rates Paid on Total Deposits to Bank Risk Characteristics

\begin{tabular}{|c|c|c|c|c|c|c|c|}
\hline \multirow{2}{*}{ Explanatory Variables } & \multirow{2}{*}{$\begin{array}{l}\text { Post-crisis } \\
\text { Oct99-Jan03 }\end{array}$} & \multicolumn{6}{|c|}{ Overlapping post-crisis supperiods (rolling window of one year) } \\
\hline & & Oct99-Jul00 & Apro0-Jan01 & Oct00-Jul01 & Apr01-Jan02 & Oct01-Jul02 & Apr02-Jan03 \\
\hline Capital / Total assets & $-0,004$ & $-0,016$ & 0,004 & $-0,016$ & $-0,007$ & $-0,010$ & $-0,004$ \\
\hline t-statistic & $-1,13$ & $-1,49$ & 0,48 & $-2,12$ & $-1,16$ & $-1,30$ & $-0,72$ \\
\hline Liquid assets / Demand liabilities & $-0,001$ & $-0,001$ & $-0,002$ & $-0,001$ & $-0,001$ & $-0,001$ & $-0,001$ \\
\hline t-statistic & $-1,81$ & $-1,14$ & $-1,41$ & $-1,13$ & $-0,57$ & $-1,05$ & $-0,56$ \\
\hline Change in loan quality & $-0,003$ & 0,004 & $-0,011$ & 0,006 & 0,004 & $-0,012$ & 0,000 \\
\hline t-statistic & $-0,64$ & 0,59 & $-0,85$ & 1,18 & 1,23 & $-0,88$ & 0,00 \\
\hline Return on assets & $-0,007$ & $-0,004$ & 0,026 & 0,018 & $-0,002$ & $-0,001$ & $-0,031$ \\
\hline t-statistic & $-0,48$ & $-0,13$ & 1,02 & 1,18 & $-0,18$ & $-0,04$ & $-0,54$ \\
\hline Excess reserves / Total assets & $-0,005$ & 0,001 & 0,009 & $-0,010$ & 0,004 & $-0,006$ & $-0,001$ \\
\hline t-statistic & $-1,69$ & 0,10 & 1,64 & $-2,02$ & 0,88 & $-1,51$ & $-0,30$ \\
\hline Loans to non-banks / Total assets & 0,000 & $-0,001$ & 0,001 & $-0,011$ & $-0,001$ & 0,003 & $-0,002$ \\
\hline t-statistic & 0,13 & $-0,06$ & 0,08 & $-1,14$ & $-0,09$ & 0,52 & $-0,50$ \\
\hline Loans to households / Loans to non-banks & 0,010 & 0,008 & $-0,009$ & 0,017 & $-0,002$ & 0,005 & 0,003 \\
\hline$t$-statistic & 2,08 & 1,17 & $-0,61$ & 2,03 & $-0,48$ & 1,40 & 1,12 \\
\hline Term deposits / Total deposits & 0,024 & 0,023 & 0,008 & 0,015 & 0,010 & 0,010 & 0,005 \\
\hline$t$-statistic & 8,12 & 2,94 & 1,48 & 2,77 & 2,04 & 3,46 & 1,81 \\
\hline Personnel expenses / Total assets & $-0,458$ & $-0,198$ & $-0,044$ & $-0,370$ & $-0,069$ & $-0,275$ & $-0,211$ \\
\hline t-statistic & $-6,25$ & $-1,86$ & $-0,62$ & $-3,31$ & $-1,14$ & $-2,98$ & $-1,71$ \\
\hline Number of observations & 16858 & 4904 & 4859 & 4863 & 4874 & 4724 & 4658 \\
\hline Number of banks & 1376 & 1302 & 1265 & 1264 & 1262 & 1253 & 1259 \\
\hline R-squared & 0,30 & 0,14 & 0,12 & 0,34 & 0,69 & 0,56 & 0,74 \\
\hline F-test fixed effects (p-value) & 0,00 & 0,00 & 0,00 & 0,00 & 0,00 & 0,00 & 0,00 \\
\hline
\end{tabular}


Table 5. Split by Legal Status of Depositors

\begin{tabular}{|c|c|c|c|c|c|c|c|c|c|}
\hline \multirow{3}{*}{ Explanatory Variables } & \multicolumn{3}{|c|}{ Firms } & \multicolumn{3}{|c|}{ Households } & \multicolumn{3}{|c|}{ Banks } \\
\hline & \multicolumn{2}{|c|}{ Deposit Growth } & \multirow{2}{*}{$\begin{array}{c}\text { Deposit rate } \\
\text { Post-crisis }\end{array}$} & \multicolumn{2}{|c|}{ Deposit Growth } & \multirow{2}{*}{$\begin{array}{c}\text { Deposit rate } \\
\text { Post-crisis }\end{array}$} & \multicolumn{2}{|c|}{ Deposit Growth } & \multirow{2}{*}{$\begin{array}{c}\text { Deposit rate } \\
\text { Post-crisis }\end{array}$} \\
\hline & Pre-crisis & Post-crisis & & Pre-crisis & Post-crisis & & Pre-crisis & Post-crisis & \\
\hline Capital / Total assets & 0,211 & 0,584 & $-0,009$ & 0,069 & 0,277 & $-0,006$ & 0,218 & 0,227 & $-0,018$ \\
\hline t-statistic & 4,04 & 7,95 & $-2,51$ & 1,23 & 2,97 & $-0,62$ & 1,77 & 2,26 & $-1,63$ \\
\hline Liquid assets / Demand liabilities & 0,069 & 0,132 & 0,000 & 0,035 & 0,060 & $-0,002$ & $-0,080$ & $-0,002$ & $-0,003$ \\
\hline t-statistic & 3,34 & 5,74 & 0,52 & 1,23 & 2,75 & $-1,79$ & $-1,39$ & $-0,09$ & $-1,96$ \\
\hline Change in loan quality & $-0,550$ & $-0,784$ & 0,001 & $-0,537$ & $-0,285$ & $-0,003$ & $-0,388$ & $-0,631$ & $-0,004$ \\
\hline t-statistic & $-4,56$ & $-3,65$ & 0,68 & $-2,78$ & $-2,20$ & $-0,30$ & $-0,94$ & $-1,90$ & $-0,18$ \\
\hline Return on assets & 0,810 & 0,050 & 0,010 & 1,390 & 0,561 & 0,012 & 0,332 & 1,405 & 0,043 \\
\hline t-statistic & 2,18 & 0,09 & 1,95 & 3,94 & 1,66 & 0,45 & 0,25 & 1,83 & 0,80 \\
\hline Excess reserves / Total assets & $-0,197$ & $-1,028$ & 0,003 & $-0,243$ & 0,033 & 0,011 & 0,332 & 0,454 & $-0,012$ \\
\hline t-statistic & $-1,57$ & $-10,93$ & 1,77 & $-1,01$ & 0,28 & 1,25 & 0,44 & 2,60 & $-0,76$ \\
\hline Loans to non-banks / Total assets & $-0,029$ & 0,293 & 0,005 & $-0,078$ & 0,242 & 0,010 & $-0,265$ & $-0,013$ & 0,004 \\
\hline t-statistic & $-0,56$ & 3,78 & 2,64 & $-1,34$ & 2,83 & 1,23 & $-2,63$ & $-0,17$ & 0,39 \\
\hline Loans to households / Loans to non-banks & $-0,049$ & 0,002 & 0,001 & $-0,100$ & $-0,224$ & 0,042 & 0,143 & $-0,168$ & $-0,010$ \\
\hline$t$-statistic & $-0,76$ & 0,03 & 0,40 & $-1,53$ & $-2,64$ & 4,83 & 0,89 & $-2,48$ & $-0,80$ \\
\hline Term deposits / Total deposits & 0,201 & 0,515 & 0,009 & $-0,462$ & $-1,024$ & 0,012 & $-0,135$ & $-0,120$ & 0,006 \\
\hline t-statistic & 4,90 & 8,50 & 5,00 & $-9,78$ & $-13,91$ & 1,85 & $-1,85$ & $-2,29$ & 0,91 \\
\hline Personnel expenses / Total assets & & 7,527 & $-0,060$ & & 0,143 & $-1,281$ & & 1,304 & $-0,438$ \\
\hline t-statistic & & 4,65 & $-2,41$ & & 0,12 & $-6,49$ & & 0,79 & $-1,89$ \\
\hline Number of observations & 9059 & 16952 & 16575 & 8471 & 15716 & 15172 & 3607 & 5890 & 7148 \\
\hline Number of banks & 1656 & 1386 & 1378 & 1598 & 1304 & 1301 & 834 & 872 & 1040 \\
\hline R-squared & 0,05 & 0,12 & 0,57 & 0,06 & 0,04 & 0,24 & 0,03 & 0,01 & 0,10 \\
\hline F-test fixed effects (p-value) & 0,35 & 0,00 & 0,00 & 0,98 & 0,00 & 0,00 & 1,00 & 1,00 & 0,00 \\
\hline
\end{tabular}




\begin{tabular}{|c|c|c|c|c|c|c|c|c|c|c|}
\hline \multicolumn{11}{|c|}{ Table 6. Robustness checks } \\
\hline \multirow{3}{*}{ Explanatory Variables } & \multicolumn{2}{|c|}{ All Banks } & \multicolumn{2}{|c|}{ Non-state Banks } & \multicolumn{6}{|c|}{ Only Non-pocket banks } \\
\hline & \multirow[b]{2}{*}{$D$} & \multirow[b]{2}{*}{$I$} & \multirow[b]{2}{*}{$D$} & \multirow[b]{2}{*}{$I$} & \multicolumn{2}{|c|}{ Legal definition } & \multicolumn{2}{|c|}{ Definition 1} & \multicolumn{2}{|c|}{ Definition 2} \\
\hline & & & & & $D^{\circ}$ & $I$ & $D$ & $I$ & $D$ & $I$ \\
\hline Capital / Total assets & 0,693 & $-0,004$ & 0,690 & $-0,004$ & 0,699 & $-0,006$ & 0,666 & $-0,006$ & 0,667 & $-0,007$ \\
\hline t-statistic & 10,06 & $-1,13$ & 9,98 & $-1,05$ & 9,82 & $-1,43$ & 8,57 & $-1,41$ & 7,08 & $-1,35$ \\
\hline Liquid assets / Demand liabilities & 0,120 & $-0,001$ & 0,122 & $-0,001$ & 0,121 & $-0,001$ & 0,134 & $-0,001$ & 0,105 & $-0,001$ \\
\hline t-statistic & 5,17 & $-1,81$ & 5,21 & $-2,16$ & 5,00 & $-1,91$ & 4,96 & $-1,95$ & 3,71 & $-1,34$ \\
\hline Change in loan quality & $-0,751$ & $-0,003$ & $-0,753$ & $-0,003$ & $-0,739$ & $-0,002$ & $-0,651$ & $-0,003$ & $-0,277$ & $-0,004$ \\
\hline t-statistic & $-2,98$ & $-0,64$ & $-2,97$ & $-0,67$ & $-2,70$ & $-0,37$ & $-2,12$ & $-0,62$ & $-0,88$ & $-0,62$ \\
\hline Return on assets & 0,301 & $-0,007$ & 0,333 & $-0,007$ & 0,344 & $-0,004$ & 0,309 & $-0,008$ & 0,194 & $-0,004$ \\
\hline t-statistic & 0,55 & $-0,48$ & 0,61 & $-0,46$ & 0,60 & $-0,23$ & 0,50 & $-0,49$ & 0,27 & $-0,26$ \\
\hline Excess reserves / Total assets & $-0,813$ & $-0,005$ & $-0,821$ & $-0,006$ & $-0,815$ & $-0,006$ & $-0,842$ & $-0,007$ & $-0,757$ & $-0,007$ \\
\hline t-statistic & $-9,72$ & $-1,69$ & $-9,69$ & $-1,77$ & $-9,40$ & $-1,80$ & $-8,51$ & $-1,87$ & $-6,21$ & $-1,48$ \\
\hline Loans to non-banks / Total assets & 0,286 & 0,000 & 0,286 & 0,000 & 0,286 & 0,001 & 0,287 & 0,001 & 0,265 & $-0,002$ \\
\hline t-statistic & 3,84 & 0,13 & 3,80 & 0,04 & 3,69 & 0,32 & 3,19 & 0,19 & 2,25 & $-0,42$ \\
\hline Loans to households / Loans to non-banks & 0,011 & 0,010 & 0,010 & 0,010 & 0,013 & 0,011 & 0,032 & 0,007 & 0,013 & 0,012 \\
\hline t-statistic & 0,19 & 2,08 & 0,17 & 2,12 & 0,23 & 2,09 & 0,53 & 1,34 & 0,19 & 2,44 \\
\hline Term deposits / Total deposits & $-0,007$ & 0,024 & $-0,012$ & 0,024 & $-0,007$ & 0,024 & $-0,030$ & 0,024 & $-0,059$ & 0,023 \\
\hline t-statistic & $-0,13$ & 8,12 & $-0,23$ & 8,08 & $-0,14$ & 7,91 & $-0,48$ & 7,07 & $-0,76$ & 4,80 \\
\hline Personnel expenses / Total assets & 6,190 & $-0,458$ & 6,153 & $-0,457$ & 6,167 & $-0,460$ & 5,709 & $-0,419$ & 5,480 & $-0,345$ \\
\hline t-statistic & 4,21 & $-6,25$ & 4,15 & $-6,17$ & 4,09 & $-6,09$ & 3,35 & $-5,09$ & 2,40 & $-3,68$ \\
\hline Number of observations & 16954 & 16858 & 16647 & 16552 & 16095 & 16003 & 12135 & 12054 & 7364 & 7300 \\
\hline Number of banks & 1386 & 1376 & 1359 & 1349 & 1312 & 1303 & 1012 & 1004 & 647 & 639 \\
\hline R-squared & 0,10 & 0,30 & 0,11 & 0,30 & 0,10 & 0,30 & 0,11 & 0,28 & 0,09 & 0,26 \\
\hline F-test fixed effects (p-value) & 0,00 & 0,00 & 0,00 & 0,00 & 0,00 & 0,00 & 0,00 & 0,00 & 0,00 & 0,00 \\
\hline
\end{tabular}


Table 7. Supply of Total Deposits

Explanatory V ariables

\section{Capital / Total assets}

t-statistic

Liquid assets / Demand liabilities

t-statistic

t-statistic

Excess reserves / Total assets

t-statistic

Loans to non-banks / Total assets

t-statistic

Term deposits / Total deposits

t-statistic

Personnel expenses / Total assets

t-statistic

Interest rate

t-statistic

Interest rate ^2

t-statistic

Interest rate * (1-Capital)

t-statistic

Interest rate * (1-Capital)^2

t-statistic

Number of observations

Number of banks

AR(2) p-value

Hansen test p-value

Implied switching point
Change in loan quality

Non-state Banks

All Banks

s

\begin{tabular}{|c|c|c|c|c|c|c|c|c|c|}
\hline 2,107 & 2,311 & 2,111 & 2,294 & 2,087 & 2,261 & 2,076 & 2,259 & 1,974 & 2,095 \\
\hline 13,09 & 10,51 & 13,08 & 10,61 & 13,09 & 10,45 & 11,48 & 9,06 & 9,65 & 7,84 \\
\hline 0,226 & 0,232 & 0,225 & 0,233 & 0,231 & 0,239 & 0,254 & 0,262 & 0,219 & 0,225 \\
\hline 6,20 & 6,34 & 6,07 & 6,24 & 5,93 & 6,09 & 5,85 & 5,98 & 4,11 & 4,22 \\
\hline$-0,771$ & $-0,750$ & $-0,763$ & $-0,743$ & $-0,753$ & $-0,732$ & $-0,609$ & $-0,604$ & $-0,281$ & $-0,272$ \\
\hline$-2,81$ & $-2,61$ & $-2,78$ & $-2,58$ & $-2,60$ & $-2,39$ & $-1,95$ & $-1,81$ & $-0,81$ & $-0,71$ \\
\hline$-1,540$ & $-1,514$ & $-1,538$ & $-1,517$ & $-1,550$ & $-1,528$ & $-1,600$ & $-1,580$ & $-1,458$ & $-1,428$ \\
\hline$-12,79$ & $-13,49$ & $-13,10$ & $-13,54$ & $-13,09$ & $-13,43$ & $-11,96$ & $-12,24$ & $-9,04$ & $-9,09$ \\
\hline 0,611 & 0,620 & 0,608 & 0,615 & 0,634 & 0,637 & 0,586 & 0,602 & 0,676 & 0,680 \\
\hline 3,91 & 4,34 & 3,97 & 4,31 & 4,15 & 4,42 & 3,11 & 3,41 & 2,78 & 2,88 \\
\hline 0,310 & 0,291 & 0,309 & 0,289 & 0,307 & 0,285 & 0,255 & 0,233 & 0,243 & 0,230 \\
\hline 2,70 & 2,67 & 2,72 & 2,66 & 2,67 & 2,56 & 1,85 & 1,74 & 1,42 & 1,36 \\
\hline 14,458 & 14,087 & 14,268 & 13,916 & 14,311 & 13,972 & 13,759 & 13,571 & 13,311 & 12,961 \\
\hline 5,04 & 5,07 & 5,01 & 5,00 & 4,98 & 4,94 & 4,21 & 4,20 & 2,87 & 2,84 \\
\hline 14,564 & 22,941 & 13,507 & 21,647 & 13,153 & 21,171 & 14,609 & 21,916 & 12,438 & 16,151 \\
\hline 1,95 & 2,97 & 2,04 & 2,85 & 2,11 & 2,84 & 2,09 & 2,65 & 2,08 & 2,14 \\
\hline$-124,359$ & $-98,466$ & $-115,800$ & $-94,103$ & $-110,010$ & $-91,084$ & $-115,563$ & $-96,871$ & $-79,520$ & $-65,295$ \\
\hline \multirow[t]{5}{*}{$-2,05$} & $-2,33$ & $-2,22$ & $-2,47$ & $-2,27$ & $-2,49$ & $-2,41$ & $-2,53$ & $-2,41$ & $-2,34$ \\
\hline & $-35,305$ & & $-33,961$ & & $-33,645$ & & $-31,668$ & & $-23,233$ \\
\hline & $-2,20$ & & $-2,21$ & & $-2,19$ & & $-1,86$ & & $-1,46$ \\
\hline & 23,744 & & 23,225 & & 23,655 & & 21,948 & & 17,422 \\
\hline & 2,21 & & 2,21 & & 2,26 & & 1,93 & & 1,71 \\
\hline 16518 & 16518 & 16221 & 16221 & 15679 & 15679 & 11775 & 11775 & 7066 & 7066 \\
\hline 1359 & 1359 & 1332 & 1332 & 1286 & 1286 & 987 & 987 & 622 & 622 \\
\hline 0,48 & 0,24 & 0,36 & 0,20 & 0,37 & 0,23 & 0,51 & 0,37 & 0,16 & 0,13 \\
\hline 0,16 & 0,10 & 0,16 & 0,10 & 0,11 & 0,09 & 0,57 & 0,37 & 0,51 & 0,30 \\
\hline 0,06 & 0,12 & 0,06 & 0,12 & 0,06 & 0,12 & 0,06 & 0,11 & 0,08 & 0,12 \\
\hline
\end{tabular}

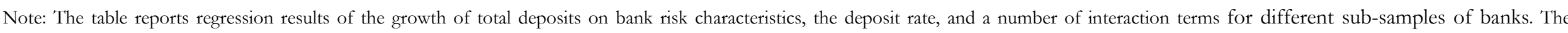

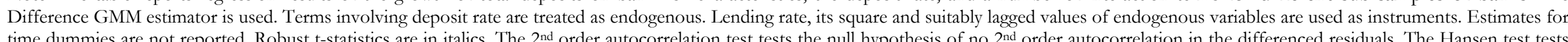

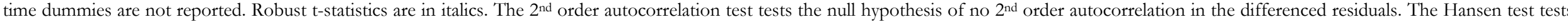
the validity of over-identifying restrictions and is robust to heteroscedasticity. Only results for the post-crisis period are reported due to the data limitations. 
Table 8. Supply of Total Deposits: Split by Total Assets

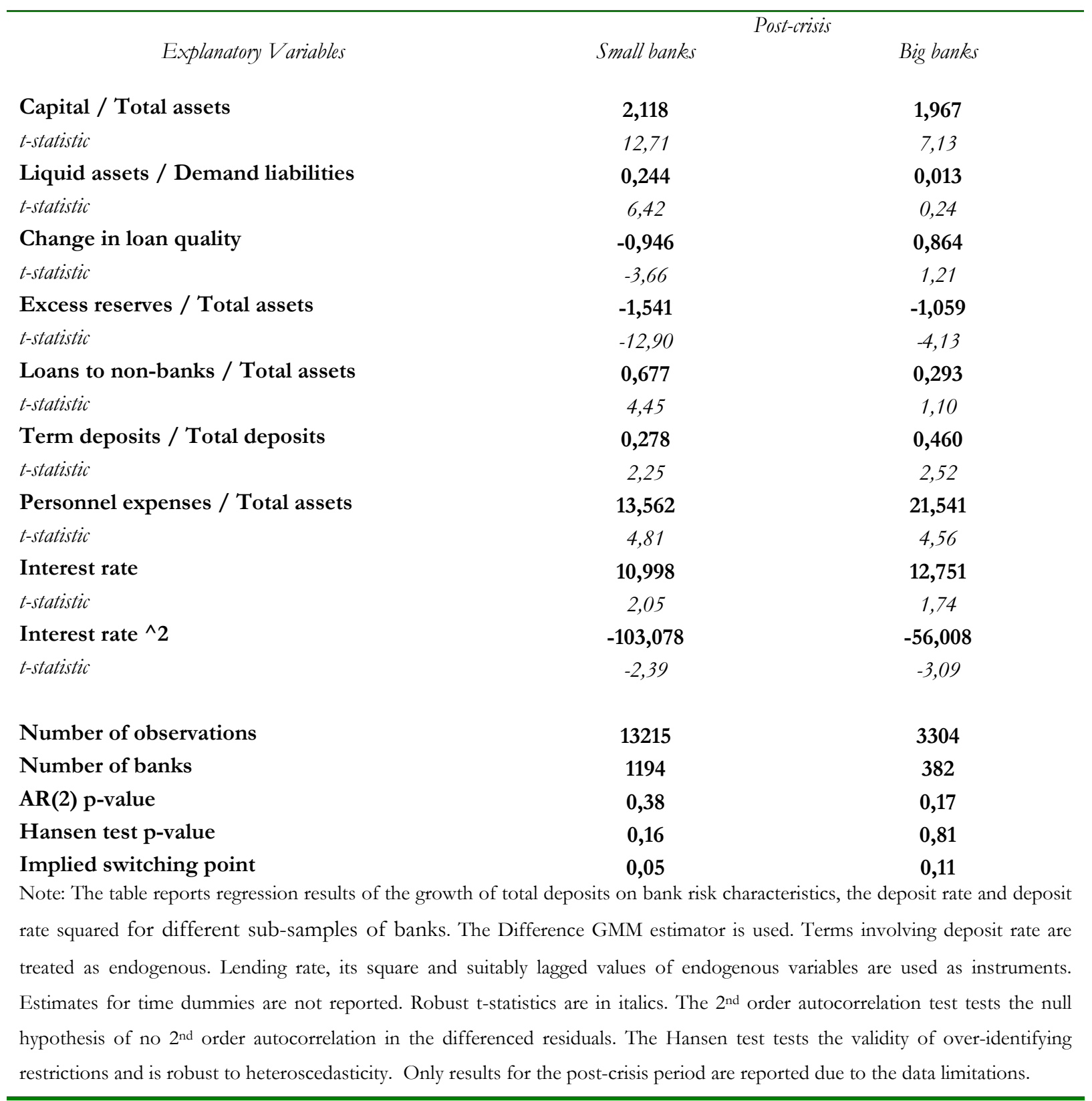




\section{Figure 1. Implied Deposit Growth in the Deposit Rate - Capital Space.}

Based on the estimated supply function (see Table 7) for different interest rates and capitalisation the figure shows implied deposit growth. Other regressors are assumed constant and are taken at their average values. Panel A represents a specification for all banks, while panel B for non-insider banks based on definition 2.

Panel A.

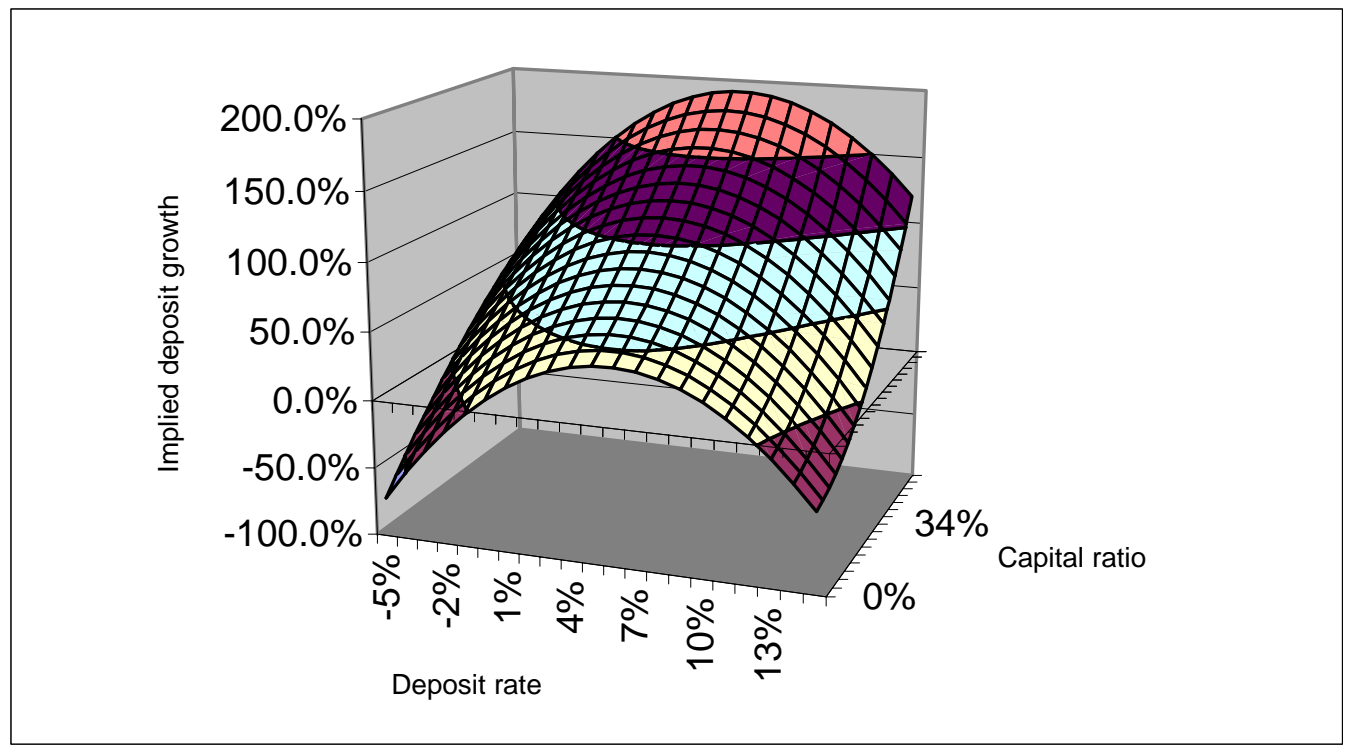

Panel B.

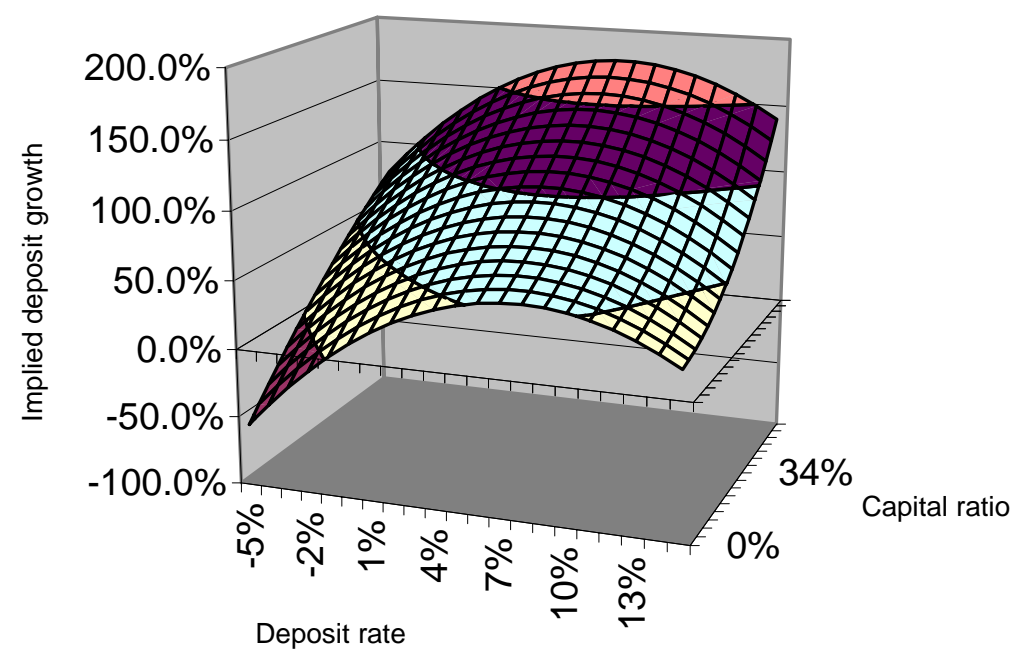


Figure 2. Implied Deposit Growth: Split by Bank Size.

Based on the estimated supply function (see Table 8) for different interest rates the figure shows implied deposit growth. Other regressors are assumed constant and are taken at their average values.

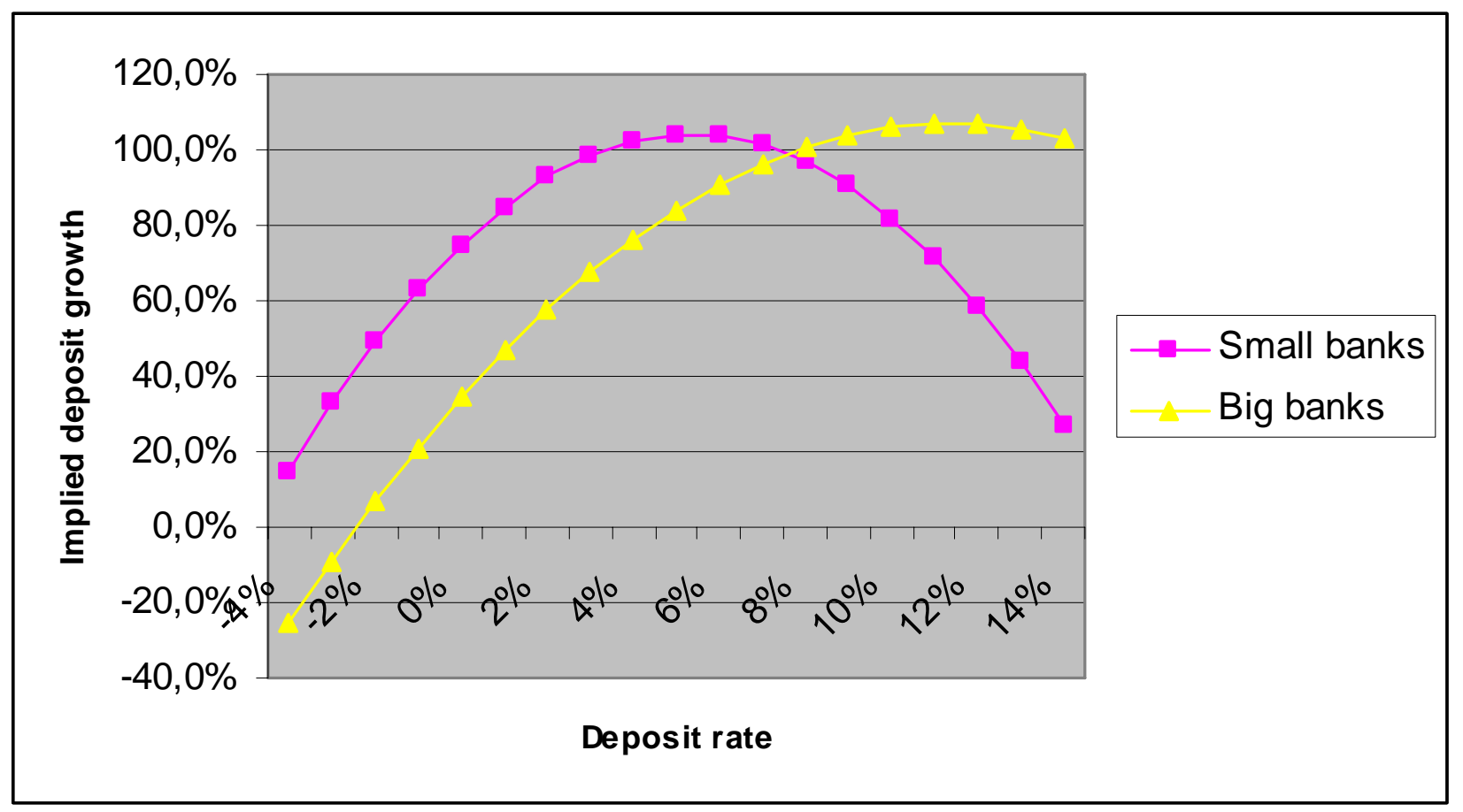


${ }^{1}$ In Hellman et al.'s model (1998, 2000), deposit rate competition among banks lowers their franchise value and, with it, incentives for making non-risky loans. The quote in the text above is taken from the working paper version (1998), which considers this competition in a world without deposit insurance. In an unpublished paper, Hanousek and Roland (2001) model a similar relationship and offer some empirical support from the Czech Republic.

${ }^{2}$ Stiglitz (1994), one of the article's co-authors, suggests in a book on post-communist reform that it would be unrealistic to rely on the private market to discipline banks: "Individuals have neither the capacity nor the incentive, even in the absence of deposit insurance, to monitor effectively (247).”

3 The following considerations are factored positively into a country's score on the PSM index: (1) whether a certified external audit of the bank's financial statement is required; (2) whether all of the ten biggest banks are rated by international rating agencies; (3) whether income statements include accrued or unpaid interest or principal on non-performing loans and whether banks are required to produce consolidated financial statements; (4) whether off-balance sheet items are disclosed to the public; (5) whether banks must disclose risk management procedures to the public; and (6) whether subordinated debt is allowable as a part of regulatory capital. The version of the PSM index presented in Barth et al. (2006) is slightly modified to include the percentage of the ten biggest banks rated by domestic rating agencies; since there is no entry for Russia in this sub-category, its PSM index is not reported. The authors' measures of bank transparency paint a similar picture. With respect to both the quality of its bank audit regime and its pace in adopting best practice accounting standards, Russia is ranked in the bottom third of countries surveyed. Barth et al.'s (2004) PSM index for Russia, 5, lags behind those of the countries covered in the analysis of Martinez-Peria and Schmukler (2001): Argentina and Chile, both 8, and Mexico, 6.

${ }^{4}$ The panel is unbalanced because some banks fail, some merge, and some are founded during the sample period.

${ }^{5}$ Controlling for time dummies in the models is equivalent to including all variables in deviations from their timespecific means. Consider model (1). In such a specification, risk measures do not affect the average deposit growth 
in the banking sector but rather the bank-specific deviations from that average. As long as banks maintain stronger than average fundamentals they enjoy higher than average deposit growth by "stealing" deposits from weak banks.

${ }^{6}$ Martinez-Peria and Schmukler (2001) note that using net deposit flows alone may not allow distinctions to be drawn between market and regulatory discipline. That is, regulatory pressure on under-capitalized banks could result in a bank deciding to reduce both its assets and liabilities, accomplishing the latter through reduced deposit rates.

${ }^{7}$ Small sample size prevents us from doing a meaningful analysis for the group of state-owned banks alone. In many emerging market economies, depositors' willingness and ability to monitor banks is influenced by the presence of large state-owned and/or foreign-owned banks. The deposits of the former often carry an implicit, if not explicit, insurance guarantee. And foreign banks may be recognized as already being exposed to discipline by the international markets on which their debt and equity trade (Caprio and Honohan, 2004). Relative to its level of development, however, Russia (during our period of analysis) had neither a relatively large state nor foreign-owned banking sector (Barth et al., 2006). In 2001, for example, over half of the banking system's assets were held at privately owned, domestic banks.

8 Considering the effect of the average (implicit) lending rate and the total demand for deposits, it is unclear to what extent it works through the demand for deposits of households, firms and/or banks. This uncertainty makes the overall average lending rate a weaker instrument for the implicit deposit rates that apply to actors of a particular type (i.e., households, firms or banks). Therefore, we estimate the supply function for all deposits together.

${ }^{9}$ See Berezanskaya (2003) for some further anecdotal evidence.

${ }^{10}$ For more information on these firms, see their respective websites at www.interfax.ru and www.mobile.ru. Karas and Schoors (2005) provide a detailed description of the datasets and confirm the consistency of different data sources. 
${ }^{11}$ Given the relatively small number of mergers and acquisitions (30) in comparison to the number of banks in our sample (about 1500), we do not expect that a different treatment of mergers would have a significant impact on our results.

${ }^{12}$ Taking into account the imperfect nature of such a measure, we had to drop unreasonable values and outliers to prevent them from driving our regression results. Given the high interest rates after the 1998 crisis we decided to treat all rates below 50\% as reasonable. Other cut-off points were examined as well, but the regression results always remained qualitatively unchanged.

${ }^{13}$ Since inflation is not observable ex ante, we have to approximate the real return investors expect to earn on their deposits by the realized real rate ex post. Assuming rational actors with optimal inflation forecasts, however, any forecast errors - i.e., differences between expected and realized inflation - should be constant across actors and should be largely captured by time dummies in the regressions.

14 The list of state-owned banks was compiled from Sherif et al. (2003), Matovnikov (2002) and Mamontov (2005).

15 Their exclusion however does not alter the results.

${ }^{16}$ For the official definition of these and other regulatory standards, see Bank of Russia Instruction No.1 of October 1, 1997, “On Bank Regulation Procedure” (an English version is available at www.cbr.ru).

${ }^{17}$ As suggested by the data in Panel B of Table II, the difference between the pre- and post-crisis results is not a function of a change in the variance of the explanatory variables.

${ }^{18}$ Roughly two percent of all observations (339 of 16518) are above this switching point. 